\title{
The European Insurance Industry: A PEST Analysis
}

\author{
Charmaine Barbara ${ }^{1}$, Dominic Cortis ${ }^{2,3, *}$, Roberta Perotti ${ }^{4}$, Claudia Sammut ${ }^{4}$ \\ and Antoine Vella ${ }^{3}$ \\ 1 Statistical Department, PSA Insurance Manager Ltd, Ta' Xbiex XBX 1122, Malta; \\ charmaine.barbara@mpsa.com \\ 2 Department of Mathematics, University of Leicester, Leicester LE1 7RH, UK \\ 3 Department of Insurance, University of Malta, Msida MSD 2080, Malta; antoine.j.vella.09@um.edu.mt \\ 4 Audit Service Line, Deloitte, B'Kara BKR3000, Malta; rperotti@deloitte.com.mt (R.P.); \\ csammut@deloitte.com.mt (C.S.) \\ * Correspondence: dc156@le.ac.uk; Tel.: +44-116-223-1794 \\ Academic Editor: Nicholas Apergis \\ Received: 3 November 2016; Accepted: 19 May 2017; Published: 31 May 2017
}

\begin{abstract}
The insurance industry plays an important role for European economic stability and the threats and opportunities it faces should be carefully determined. In this paper we highlight the main challenges by using a Political, Economic, Social and Technological (PEST) analysis. This work applies conventional actuarial thought on this area by focusing strictly on the European sector.
\end{abstract}

Keywords: insurance; PEST; political; risks; challenges; economy; European Union

JEL Classification: G10; G22; O16

\section{Introduction}

A sound insurance industry is important for a proper economic system, economic growth and promoting higher employment amongst other factors. Should such a system be uneven, especially in the non-life business sector of insurance, it may lead to higher risks in the economic decisions taken by companies and individuals. Hence, the insurance industry is beneficial for the economic system as a whole since it provides the ability to transfer, pool and mutualise risks, which helps keep a country economically stable (CEA 2006).

Linder and Ronkainen (2004) provide an important assessment of why the insurance and pensions industry is important to the European Union: it employs over one million Europeans, it is the largest institutional investor, and it provides cover against a variety of risks to a wide range of customers. For example, in 2013, an average of 1883 EUR per capita was spent in 34 European countries (Insurance Europe 2014).

Risk mitigation is the core nature of the insurance industry and hence it is highly vulnerable to a range of external forces. During the course of our lifetime we have been exposed to certain events which have altered the financial services industry. Some examples include the September 2001 terrorist attacks, flooding across Europe and the 2008 economic crisis. These events, amongst others, have shaken the insurance industry considerably. In addition, with the growing popularity of bancassurance, the distinction between the insurance industry and the banking industry is becoming ever thinner and thus the connection between these two industries needs to be constantly monitored (Schiro 2006).

Given the large scale impact that such events have on the worldwide economy and the financial industry in general, the insurance industry needs to be adequately prepared. The ultimate goal of an insurance policy is to bring policyholders back to the same position they were in before any events which have given rise to a loss occurred. Thus if claims arise companies need to have sufficient liquidity 
to be able to compensate for these losses. During catastrophic events affecting the insurance industry, insurers may experience an influx of claims and, as such, need to be prepared for such circumstances.

On the other hand, investments are one of the main sources of revenue of the insurance industry. However, companies must ensure that they strike the right balance between investments and liquidity. In the event of large scale economic events, investments may be considerably affected. In addition, given the liquidity requirements that the insurance industry faces, investments need to be sufficiently liquid to ensure that the company remains solvent throughout the course of its lifetime.

This article intends to evaluate the risks posed by external factors in the European insurance industry, by the use of a Political, Economic, Social and Technological (PEST) analysis as a tool to identify these risks. PEST analysis represents a framework of external macro-economic factors that can have an effect on the subject at hand. It can be used to assess the external pressures on a business unit, project or even an industry. PEST analysis is usually used in conjunction with a Strengths, Weaknesses, Opportunities, Threats (SWOT) analysis when evaluating a project or business. As SWOT incorporates internal factors (strengths and weaknesses), we believe it would be inappropriate to apply it to a whole industry. In our opinion it would be useful to apply SWOT when comparing different forms of insurers (say Mutuals) rather than when assessing external pressures.

PEST analysis has been applied to the insurance industry in educational settings. For example, both the Institute and Faculty of Actuaries (London, UK) and the Society of Actuaries (Schaumburg, IL, USA) include this analysis in their Business Awareness (CT9) and Fundamentals of Actuarial Practice syllabuses respectively. Indeed, we do not intend to reinvent the wheel but we need to update these and apply them to a more European level. We have developed a PEST analysis following discussions with professionals and an in-depth literature review.

The next section discusses Solvency II regulation as well as other legislative causes that might affect this industry. By political and legislative, we interpret this as any decision made by a government or administration of a jurisdiction that may impact directly or indirectly the insurance industry.

A number of economic factors such as economic growth, interest rates, exchanges rates and inflation have an impact on the future outcome and performance of insurance companies. For instance, high fluctuations in interest rates will eventually impact the magnitude of that company's capital growth. Therefore, in order to forecast the cash flow of a business, certain factors have to be assessed beforehand such as investment earning rates and inflation rates (Garrett 2013). Another example is the tendency of high unemployment rates during recessions. This may cause a higher level of claims under the employers' liability insurance or any personal accident policies to compensate injured workers who cannot return to work due to not finding a job substitute (Shepherd 2010). Recession causes household and corporate industries to decrease their demand for insurance cover and in turn causes lower premium rates (Liedtke and Schanz 2010). Furthermore, the economic and business environment effects on the European insurance industry are discussed in the next section by focusing on financial crises, interest rates, inflation, exchange rates, demographic and economic changes and the underwriting cycle.

This is followed by a discussion of how societal and cultural changes have and will continue to affect this industry. Finally, the effects of changes in the physical environment and advances in technology are evaluated.

\section{Political and Legislative Factors}

Political interventions have been seen as necessary to ensure the stabilisation of the financial services industry against a number of risks due to this industry's economic importance. One of the most effective ways in which political factors have affected the financial services industry is through the introduction of stricter regulation across the whole industry. When taking into account the recent economic events (such as the 2007 financial crisis) that have impacted the whole European economy, political forces have tried to harmonise EU legislation so that there will be a common ground on which the financial services industry is regulated. 
One such example is the introduction of Solvency II (SII), an EU Directive that codifies and harmonises the legislative framework for insurance and reinsurance undertakings. The main objectives of such a directive include:

1. A uniform and enhanced level of policyholder protection across the EU;

2. A more modernised supervision process which will introduce a more widespread supervision and monitoring of the insurers' risk profiles and the quality of their risk management and governance systems;

3. A more integrated EU market; and

4. An increased international competitiveness between EU insurers (Doff 2008).

SII is based on three pillars. The first pillar sets the quantitative requirements for an insurance undertaking to be able to operate. This is evaluated as a Value-at-Risk at a $99.5 \%$ percentile measure over one year. The Value-at-Risk can be derived using a standard formula or internal model. The second pillar defines the risk management controls within an insurance undertaking while the third pillar requires additional disclosure (Linder and Ronkainen 2004).

The introduction of such legislation can be considered fruitful to the European financial services industry as it reduces regulatory arbitrage but it could also be argued that SII was a very expensive undertaking based on the proportion of insurance services that are cross border. Stricter legislation brings about an additional burden on insurance companies, especially captives. ${ }^{1}$ SII does however include a proportionality principle which ensures that the legislation is not too burdensome and takes account of specific institutions and industries. Such principle takes into account the scale, nature and complexity of the insurance undertaking.

Notwithstanding this, most insurance companies still feel that this new regulatory framework will introduce strategic and compliance challenges. One additional burden that such legislation has introduced is the increase of the capital base needed, that is Pillar I of this directive. This pillar addresses the quantitative requirements including the calculation of the Solvency Capital Requirement (SCR), the Minimum Capital Requirement (MCR) and technical provisions (or reserves) (Vaughan 2009). Most insurance undertakings need to hold additional capital to be in line with these requirements. Despite this, SII is generally not prescriptive in nature. For instance, it allows insurance companies to decide on their own risk appetite and to develop their own internal models which is commensurate to their own risks, subject to regulatory approval (Ernst \& Young 2010). It is however prescriptive for smaller firms without resources to do a full Own Risk and Solvency Assessment (ORSA) exercise.

In addition, greater costs will be incurred by these firms with the new rules governing how they will be identifying, monitoring and mitigating certain risks and to ensure that they possess the proper systems in order to adhere to the disclosure requirements imposed on these undertakings. Thus, this could result in the companies being less profitable or increasing their prices to reflect the costs incurred. One should also note that this increase in costs (because of new legislation) is also experienced by the regulatory bodies (Crespi 2005).

Apart from introducing regulatory measures, governments may decide to introduce laws that affect just one class of insurance. Such decisions can impact the industry as a whole. For instance, the government may decide to remove the third party liability motor insurance from being compulsory. Such legislation would considerably affect insurance companies which offer this type of insurance because there would be a decrease in demand for such insurance cover. In addition, such an example could lead to an increase in competition especially since many insurance companies offer motor insurance and this may, in turn, lead to a reduction in premium prices. Another such example is if the government decided to reduce the amount of free healthcare in a country. In such a case, the demand for health insurance would increase considerably. Furthermore, this might lead to an increase

1 Insurance companies established by the parent company for the specific purpose of insuring the parent company's risks. 
in premium prices because of the high demand and the higher probability of a claim. Alternatively the size of the market might attract larger players and greater price competition.

The government may have a more indirect effect on the industry. For instance, an increase in enforcement could considerably impact insurers. For example, the government may decide to make stricter rules in relation to the wearing of seatbelts or on drinking and driving. This may lead to less car accidents which would result in fewer claims for insurers.

Judicial decisions could also prove to affect the financial services industry. For example, if an insurance policy wording is unclear or has inconsistencies, this could lead to a case taken to arbitration or to the courts of law and the decision could pave the way for unforeseen claims. One such example was the case where a baby quad-bike was stolen. The insured assumed that this was covered under the household policy since the explanatory leaflet (policy wording) given to the insured did not exclude such events. However, the policy document contradicted this. The Ombudsman ruled that the insured should be compensated because it was the insurer who produced inconsistent information (Summer 2010).

Apart from the legislative part of political forces, the political environment of a country affects the insurance industry as a whole. Governments which have a very strict regulatory regime would pose greater regulatory risks on the insurance industry. However, such regulation could be key in the country's dealings with catastrophic risks since the undertakings would be sufficiently prepared in meeting the aftermath of such risks. On the other hand, a lax regulatory regime could promote decreased regulatory risks and fewer costs for undertakings to be compliant with the regulations at the expense of increased risk to policyholders. One of the reasons why SII was introduced was to harmonise regulations as well as reduce regulatory arbitrage. Unlike other jurisdictions, Europe-wide regulatory change does not tend to be unpredictable in nature but can be predicted decades in advance, as experienced in SII.

Furthermore, political forces could prove to be vital in the attraction of insurance firms to their particular countries. Tax incentives for companies setting up in a particular jurisdiction and the introduction of the Euro may provide the country with additional investment opportunities. Such incentives give certain states the upper hand and would bring about an increased investment activity especially since some of the countries mentioned are limited in terms of local investments. The introduction of retirement schemes in Malta is one example. Such retirement schemes target UK residents which opt to transfer their benefits from a registered pension scheme or a relevant non-UK scheme to these Qualifying Recognised Overseas Pension Scheme (QROPS). Given that Malta has a double taxation treaty with the UK, then the members of the scheme would benefit from a reduction in tax charges (Tye and Latrémolière 2007). These developments are the result of globalisation, as free trade across borders becomes more accessible, many can shift to improve efficiency, reduce costs and at times for regulatory arbitrage. Yet, the current climate of deglobalisation and protectionism might reverse this process. For example, international insurance groups may start considering matching their assets and liabilities per jurisdiction rather than as a whole group.

\section{Economical and Business Environment}

\subsection{Financial Crises}

Severe economic crises are bound to have an effect across different industries. Due to their very nature, their effects are hard to predict. A case in point is the financial meltdown experienced between 2007 and 2009. This crisis was an amalgamation of various issues including the fall in security values accentuated by a housing price bubble and in mortgage defaults. This in turn caused reduction in mortgage related securities and thus led to an even bigger crisis (Harrington 2009).

While its effect on the banking industry was far bigger than that experienced by the insurance industry, the latter did not come out of this unscathed. The International Monetary Fund (IMF) 
reported total losses amounting to US $\$ 4.1$ trillion of which two thirds were incurred by banks and one third by insurers, pension funds and other financial institutions (IMF 2009).

Harrington (2009) identifies various causes to the financial crisis-one of which being banks having expanded their mortgage lending to low income home buyers, mortgage lending with low interest rates (leading to an increase in housing demand) and a high growth in Credit Default Swaps (CDS). The combination of these caused house price declines and mortgage defaults. Having insurance and CDS as a coverage on any default by the subprime borrowers contributed to a higher lending by banks. On the other hand, sellers of CDS such as the American International Group (AIG) became highly vulnerable to the increase in mortgage defaults.

AIG suffered greatly during this financial crisis due to its CDS portfolio offered through its British subsidiary; in fact, it was about to file bankruptcy. The United States government believed it could not let this happen as otherwise it would have caused economic depression, thus it bailed out AIG to the tune of $\$ 182$ billion.

A chief criticism of the financial crisis is of banking regulation that encouraged risky loans, complex off balance sheet vehicles and aggressive investment strategies amongst other activities, including allowing banks to buy a substantial amount of protection from AIG (Harrington 2009).

The insurance industry was less affected than the banking industry due to lower liquidity risk (Liedtke and Schanz 2010) and limited systemic risk (Harrington 2009). One of the reasons was that insurers do not face the risk of a client defaulting but rather the risk to pay the insured should they suffer a loss, death or maturity of a policy. Nevertheless, the insurance industry is prone to market risks. During the 2008 financial crisis, the decline in collateralised debt obligations and asset backed securities affected both banks and insurance companies. However, since insurers have increased their connections with banks and with other non-traditional insurance activities (mainly in capital markets) over the past two decades, it has been seen that systemic risk has seeped into the insurance industry and this trend is expected to continue. Both entities have increased their non-traditional activities (through diversification) and became a member of each other's markets, which in turn has created a systemic link between banks and insurers and also altered their separate business models making it almost impossible to go back to the traditional models (Baluch et al. 2011). Notwithstanding, a decreased demand for bancassurance has been experienced due to it being sensitive to market dislocations including organisational and managerial complexities (Liedtke and Schanz 2010). This does not mean that the trades between the insurance and banking industry have diminished.

On the liability side of the non-life insurance industry we find several policies offered to cover the insured when they are legally liable to pay third party damages/losses which arise out of negligence or legal wrongdoings caused by the insured-two of which include Directors and Officers (D\&O) and Errors and Omissions (E\&O) policies. Shareholders, employees or banks who suffer losses due to mismanagement by the directors/officers of the same firm may also sue such individuals due to such errors-this being covered by a D\&O policy.

During times of financial downturn, less economic activity leads to underwriters softening their rating structure, for example SwissRe (Zurich, Switzerland) reported a downturn of $0.8 \%$ in non-life premiums due to the financial crises of 2007-2009, and more claims being paid out due to a more litigious environment as well as an increase in fraudulent and exaggerated claims. Furthermore, given that this class of business is long tail, any results from the 2008 credit crunch and financial crisis will probably remain unknown for many years (Baluch et al. 2011).

Post crisis the insurance industry resumed growth in line with the global financial market (Liedtke and Schanz 2010), mainly because investors had understood that the effect on the insurance industry was less severe (Baluch et al. 2011).

Following the crisis, it was firstly expected that more mergers and acquisitions would be seen in the market, where large insurance entities, who survived the crisis, would target smaller entities that were weakened (Baluch et al. 2011). More recently new international regulations set by the Financial Stability Board have placed some companies as systemically important financial institutions 
(Sifis) which adds significant oversight at a huge cost. In this environment it may be more viable for a Sifi to sell off parts of its business in order to evade these regulatory constraints-a case in point being Generali (Trieste, Italy) selling off U.S. life reinsurance business and a Swiss private bank to not remain a Sifi (Jenkins 2016). Secondly, when it comes to selling insurance products via banks (bancassurance) it is expected that such affiliations will diminish in the future-mainly because insurers are not as keen to seek the "help" of (or acquiring interest in) banks to promote and sell their insurance products; given that insurers have suffered from problems with their bank subsidiaries. Finally, as a consequence of the crisis, it was expected that in the near future regulation and supervision would change for the insurance market (mainly by the implementation of SII). The regulatory reform in Europe, concerning guarantee funds, needs to be mitigated by providing a standard framework for deposits, investments and insurance; thereby providing harmonisation at EU level for the different financial services industries across Europe (Baluch et al. 2011).

A number of recommendations have been borne out of the crisis, including a greater focus on risk management, more control over due diligence rather than an over reliance on rating agencies, transparency and analysing policymaking, regulation and supervision both at micro and macro level and understanding the linkages between them including any emerging risks (OECD 2011).

\subsection{Interest Rates}

Changes in interest rates are likely to affect long term products and as such would be expected to have a higher impact on life insurers than on non-life insurers. The low interest rates increase the present value of liabilities. This is placing significant pressure on insurers since liabilities must be covered with assets, stressed further by an environment of high capital requirements.

Having low interest rates for such a long period will impact life insurers and their financial position as they have long term commitments to their policyholders. On the other hand, low interest rates for non-life insurers can cause insufficient returns which could have compensated weak underwriting results or offset the effects of inflation (EIOPA 2014).

Indeed, $47 \%$ of industry experts have reported that Europe is no longer a feasible market for life insurers, $53 \%$ state that the financial performance of this industry is low and $64 \%$ declare that there is stress to over-reach for yield. Such negative factors result in more harm to the industry especially when it is prone to interest rate fluctuations (Sander and Krauel 2013).

Life insurers are taking measures such as cost cutting, consolidation, balance sheet restructuring, including hedging and derivatives, and increasing reinsurance cover in order to keep their company stable and providing satisfactory profits for their shareholders. Moreover, most of these companies are entering new market industries by, for example, introducing new insurance product lines and diversifying into non-insurance business. Other measures, such as expanding outside Europe, liquidity swaps and increasing equity or direct investment and providing bonds or loan notes, will help mitigate solvency (Sander and Krauel 2013).

Over reaching for yield is the current main target of life insurance companies within Europe. They do so by engaging in risky investment strategies in order to enhance their return and boost their solvency and profit; such as decreasing their investment in government bonds and investing in hedge funds, private equity and listed equities. Moreover, insurers are getting more interconnected with banks by engaging in liquidity and interest rate swaps. Since higher return is borne from higher risk, life insurers will also engage in credit risk when they seek investment with higher yields in the bond market (Sander and Krauel 2013).

By engaging in such activities, life insurers will be risking their role as long term investors within Europe. In fact, if the low interest rates environment within Europe endures in the coming years, it is expected that insolvency amongst small and large firms will increase. The resulting increased exposure to credit risk can be mitigated by altering the product portfolio and increasing pricing. Despite the fact that this will increase costs to policyholders and lower their benefits, life insurers within Europe have already engaged in such activities (Sander and Krauel 2013). 
A report drawn up by EIOPA during December 2014 outlined various statistics showing insurers' position in Europe including their return and stability. These statistics outlined that by the second quarter of 2014, premiums for life insurers continued to grow. However, not all companies saw a growth in premium income mainly due to market fragmentation and consumer behaviour. Despite this, consumers still seek insurance cover especially when it comes to retirement benefits, knowing that state provided retirement and health benefits will potentially decrease in the long run. Demographic changes and increase in life expectancy also have an impact on such matters (EIOPA 2014).

The present situation offers the opportunity for life insurers to provide alternative investment and liquidity swaps to banks. However, for Europe to remain a viable long term market it is required by businesses to streamline their products and models (Sander and Krauel 2013).

\subsection{Inflation Rates}

Traditionally the two main causes of inflation are said to be demand pull inflation and cost push inflation. The former is when the demand for goods and services rises at a faster rate than the supply/production, leaving supply constant and in turn causes prices to increase, thus inflation. On the other hand, cost-push inflation occurs when the supply of goods and services diminish, leading to higher prices as demands remain constant.

Contrary to inflation is deflation which can be caused by a diminishment in general economic activity forcing suppliers to reduce prices; often caused by a low supply of money in the economy (Alhgrim and D'Arcy 2012).

Long term non-life insurance products, such as health insurance products, are more susceptible to economic changes due to their volatility, the reason being that, since this product provides cover for long term-care, the impact of inflation can be seen in the long run given that such a product has lengthier pay outs and claims (Alhgrim and D'Arcy 2012). On the other hand, general insurance products such as motor insurance policies have a different economic impact.

Alhgrim and D'Arcy (2012) highlighted that inflation causes the value of items insured to increase and therefore so will claims costs. This is because the cost to repair or replace an item will be equivalent to the current market value. For instance, vehicle manufacturers have increased the cost to replace those parts which are most commonly damaged during an accident, well above the inflation rate. Hence as vehicle original parts increase in price, so will the claim costs to repair or replace. Alhgrim and D'Arcy (2012) also highlighted the fact that apart from inflation, insurers might also face higher medical care costs due to continuous advances in modern medicine. Therefore, claim costs will be higher due to higher inflation and economic adjustments, causing the costs to repair/replace to increase.

On the other hand, deflation causes risks to interest rate security (Karl et al. 2010). For life insurers, inflation has less impact on claims costs since pay-outs are mostly fixed. However, the impact of inflation is usually more indirect. For instance, inflation wears down the fixed future payments lessening the incentive for buyers to purchase life insurance policies given that inflation erodes the value of money (Alhgrim and D'Arcy 2012).

Insurers keep track of inflation by adjusting the sums insured of the properties insured accordingly. Life premium rates have to be adjusted according to the increase in wages and prices (Karl et al. 2010). Liability insurance is more prone to the social cost escalation than general price inflation, for the simple reason that technology and medical developments advance at a higher rate than inflation does. This leads to a higher rise in liability claims than in inflation. For example, in Germany the general liability claims rise $2.2 \%$ for every $1 \%$ increase in inflation (Karl et al. 2010).

Therefore, general inflation is not the only factor causing an increase in prices and claims costs. Over the past decade the price of vehicles has increased by $25 \%$, however, most of this increase is due to the advance in technology rather than the effects of inflation (Alhgrim and D'Arcy 2012). The same effect is experienced in medical care as the unremitting advance in medical technology has caused higher claims costs when compared to payments for medical procedures decades ago. 
Furthermore, Alhgrim and D'Arcy (2012) state that wages rise in line with inflation which also has an impact on the workers' compensation scheme given that these are adjusted according to wages when loss occurred; hence liability by insurers will have to be adjusted accordingly.

\subsection{Foreign Exchange Rates}

Many large EU insurance companies have expanded worldwide through merger and acquisitions as was forecasted after the economic crises. This has caused such companies to face foreign exchange risks, which means that insurers would face a difference in the value relationship between the currencies of their home countries and those of the foreign countries from where they are operating or in which they are investing. Therefore, such multinational insurance companies will face a higher competition in such countries (Gorvett 2001).

Furthermore it would be wrong to consider the European region as a solely Euro-currency region as it is a multi-currency environment (Parker and Barker 2015). A fluctuation in interest rates can have significant effects on the profitability of an insurer operating in jurisdictions in multiple currencies or writing business in different currencies (such as a reinsurer). Insurance companies can manage such foreign exchange risk through hedging, forward and future contracts, options and swaps.

\subsection{Demography and Economic Growth}

Shepherd (2010) explains that when income decreases following an economic crisis the mortality rate for the elderly and young children increases. This is because such families and individuals would not have enough income to spend on necessities such as medicine, food, clothing, heating, etc., which lead to poor health and thus mortality.

Demography has had an impact on insurance purchase for a number of years. For example, policyholders within EU countries have spent $8 \%$ of their social expenditure on disability insurance (more widely known as personal accident insurance) with varying degrees across EU countries due to differing demographic changes, health systems and cultural attitudes (Börsch-Supan 2010). Furthermore, the reduction in mortality rates has triggered a higher demand for pension schemes, health and social care; mainly amongst elderly people.

\subsection{The Underwriting Circle}

Underwriters are consistently adapting premiums charged, as well as terms and conditions, according to their competitors in the market. At times this is done at a loss or break even in order to maintain market share and sustain fixed costs.

A hard market with high profits attracts new insurance companies. Given that supply is high and competition is increasing, insurers will have to decrease the amount of premium charged, ending up falling below claims costs. In the long run, weak insurance companies will fail due to low capital and high liabilities sometimes caused by a catastrophic outcome, forcing them to exit the insurance market. This will only leave the stronger insurance companies in the market and due to low competition it allows them to drive higher premiums above claims costs, which in turn generates higher profits and permitting once again for the cycle to repeat itself (Grossman and Ginsburg 2004).

The underwriting cycle describes how the insurance market swings from soft markets into hard markets with the cycle repeating itself over the years. Therefore, the main reason for the cycle is the variations in supply mainly due to competition and their financial capital.

Insurance companies in Europe have gone through various underwriting cycles as a result of various economic factors, which in turn affected the industry as a whole. 


\section{Social and Cultural Environment}

\subsection{Work and Employment Patterns}

\subsubsection{Job Mobility}

In some European countries, it was common for employees to work with one employer in their lifetime and change the employer seldom, if ever. However, this has changed over time inclining towards a trend for greater job mobility, even more so for qualified persons. Hence firms' reliance on flexible or temporary employment has increased (Dwight 1996). Nowadays, it is unlikely for persons to experience a stable working life of unbroken full time employment. It is often sought-after to experience several jobs in different organisations, in order to grow professionally and expand on one's skills and experience. However, an employee changing jobs, or even careers, numerous times is fairly likely to suffer periods of enforced "retirement" or redundancy (Atkinson and Dickson 2011).

Research shows that college graduates in European countries hold on average 1.6 jobs in the first three years after graduation (Borghans and Golsteyn 2010). Employment patterns will vary from country to country due to different economic conditions, culture, social attitudes, demographics and changes in technology. In fact, Borghans and Golsteyn (2010) also found that job mobility across Europe varies significantly, with Norway and the Netherlands graduates holding approximately half a job more than those in France, Sweden and Germany. In addition, their study also shows that involuntary job separations are rare in Europe but the highest is found in Spain.

This change in lifestyle affects saving patterns for pensions in Europe by moving away from defined benefit schemes to defined contribution schemes, whereby defined benefit schemes were designed to fit a working lifetime with one employer. Thus, in response to the needs of more mobile workers and of lower skilled and unskilled workers, higher vesting, compulsory preservation and industry-based pension schemes have been introduced (Shepherd 2010). ${ }^{2}$

\subsubsection{Unemployment Rate}

European unemployment started increasing in the 1970s, rose further in the 1980s and reached a plateau in the 1990s. An increase in European unemployment led to changes in institutions, whereby most governments tried to control it by introducing employment protection, bringing about the creation of unemployment insurance. Due to financial pressures from the early 1980s, most governments have partly reversed the initial change in institutions, even though it was considered perverse at times. These were derived due to the different preliminary outcomes that played a core role in establishing the size of the increase in unemployment. Therefore, it is seen that the different paths taken explain the differences in the unemployment rates across Europe today (Blanchard 2006).

Unemployment could have a reversal effect to people taking out unemployment insurance, causing people to leave their money in banks rather than investing in an insurance policy. This demographic trend influences the types of product and service that financial institutions can market (Shepherd 2010) thus having an impact on the insurance industry. It could also impinge on the options for actuarial projections of future cash flows. Other examples resulting from unemployment may be policyholders downgrading their policy, such as switching from comprehensive to third party cover in the case of motor insurance, and increases in the likelihood of fraudulent claims. Unemployment is also essential to consider when it comes to examining the financial condition of a national pension scheme (Shepherd 2010).

2 Refer to Andrietti (2000) for further discussions of problems posed by defined benefit occupational pension plans to the free circulation of private industry workers in the European Union. 


\subsection{Maternal Employment Rates}

European society has been slowly evolving from single earner households where the husband is the chief or sole bread winner to multiple earner households (Tsang et al. 2011) and single adult households (Eurostat 2017). Multiple earner households imply a higher joint income and hence more consumption which in turns leads to higher demand for insurance. This in effect has resulted in more mothers entering the work force when their children are still young.

Governments have helped in this societal shift by introducing parental leave, maternity leave, spouse support and child care, amongst others (Scarr et al. 1989). Yet, the nature and extent of support that governments across Europe offer varies considerably. Research has shown that the Nordic welfare states offer the highest level of support. Other countries, for example France, have historically offered extensive childcare support to working mothers. It is also shown that the domestic division of labour in France has remained relatively traditional, which is associated with higher levels of work-life conflict. In Finland and Norway, there is evidence of a "societal effect" where lower levels of work-life conflict are reported, even though factors have been controlled (Crompton and Lyonette 2006).

This change can be advantageous to the insurance industry since nannies are on the rise due to the result of both parents working. Consequently, Lloyd's (London, UK) has addressed this challenge by launching a new insurance product entitled "Nannycare" which offers nannies protection for any liability claims that may arise, such as any accident or injury involving the child and property loss or damage (Business Case Studies 2013). The increase in the hire of family help can also lead to other insurance demands. For example, employing a carer or a nanny results in legal responsibility to pay pension contributions in the UK (Roberts 2015).

\subsection{Fertility, Mortality and Migration}

Family formation, trends in fertility, mortality and migration have also experienced a seismic shift over the past few decades resulting in changing demographics and socio-economic structures of societies. Consequently, they have an impact on the demand for insurance. These are all vital factors to consider when investigating the financial condition of a national pension scheme.

In Europe, fertility rates have fallen; meaning women are having fewer children over their reproductive lifetime, and are also choosing to wait until they are older before bearing their first child. This trend has been described and discussed by Frejka (2008). Complete family size is now falling and the generation gap between parents and children is increasing. Since family formation is changing, women cannot rely as much as they used to on their husbands' pension scheme to provide for them in their old age.

Eurostat (2014) confirms that fertility has steadily declined from the mid-1960s through to the turn of the century in those countries that form part of the EU today. However, it has seen that in recent years the total fertility rate in the EU is showing a slight tendency of rising again. This decrease in population could bring about a reduction in the number of people taking out insurance products.

Mortality generally increases with age but there are certain age ranges and circumstances whereby increases in age can reduce the risk of death. For example, infant mortality is usually much higher than the mortality of a ten-year-old. Europe has seen an improvement in infant mortality rates whereby it was almost halved from 1997 to 2012 (Eurostat 2014).

Particularly for males, there comes another range of high risk ages between the late teen years and early twenties arising from accidents due to high risk behaviour. In the recent past, this peak in mortality rate for adolescents was shown in mortality rate graphs as an "accident hump" (Atkinson and Dickson 2011). During this particular time, companies' insurance risk increases significantly and thus can affect the premiums charged. For example, with motor insurance, the premium is much higher for an eighteen-year-old rather than a thirty-year-old due to the perceived riskier behaviour. Recent research suggests that young male drivers' relative risk is rising which may indicate that current policies are less effective for males rather than females (Twisk and Stacey 2007). Atkinson and Dickson (2011) explain that mortality rates generally differ for males and females, with the latter being almost always 
lower than the former. This varies with age and as explained before, it is most observed during adolescence. Infant mortality is a strong indicator of the health and socio-economic prosperity of a population, and is a factor which impacts the population as a whole.

International migrant stock in Europe has been increasing over the years, with 49 million in 1990 increasing to 72.4 million in 2013. At the regional level, Europe was the largest host of international migrants in 2000 with 56.2 million, and even in 2010 with 69.2 million, followed by Asia and Northern America for both years. In 2013, it still remained the most popular destination region (OECD-UNDESA 2013). This brings more economic activity into Europe, resulting in a higher demand for the insurance industry in Europe. Yet, it also brings increased risk as it has been identified one of the two top risks by 750 experts (World Economic Forum 2016). Large-scale involuntary migration may lead to formation of ghettos and increase polarization of societies if there is a lack of effective integration policies. Moreover, it may cause more distress to social security systems (World Economic Forum 2016).

\subsection{Ageing Population}

Life expectancy is generally higher in the EU than in most other regions of the world. It is expected to keep growing, mostly from the reduction of mortality at older ages, but there are still major differences between and within countries of the EU. This will affect the population distribution such that there will be a higher proportion of individuals in retirement ages (Figure 1). The extremes of the ranges for life expectancy at birth as at 2012 are in Bulgaria and Spain for women with 77.9 and 85.5 years respectively, and Lithuania and Sweden for men with 68.4 and 79.9 years respectively. Improvements in education and standards of living have an impact on longer life expectancy, hinting that the pattern of increasing longevity could be further extended in the future. In 2012, the average life expectancy at birth in the EU was 80.3 years, reaching 83.1 years for women and 77.5 years for men. Between 2002 and 2012, life expectancy increased by 2.6 years, being 2.2 years for women and 3.0 years for men. Looking at a wider picture, over the past 50 years, it has risen by about 10 years for both men and women in the EU (Eurostat 2014).

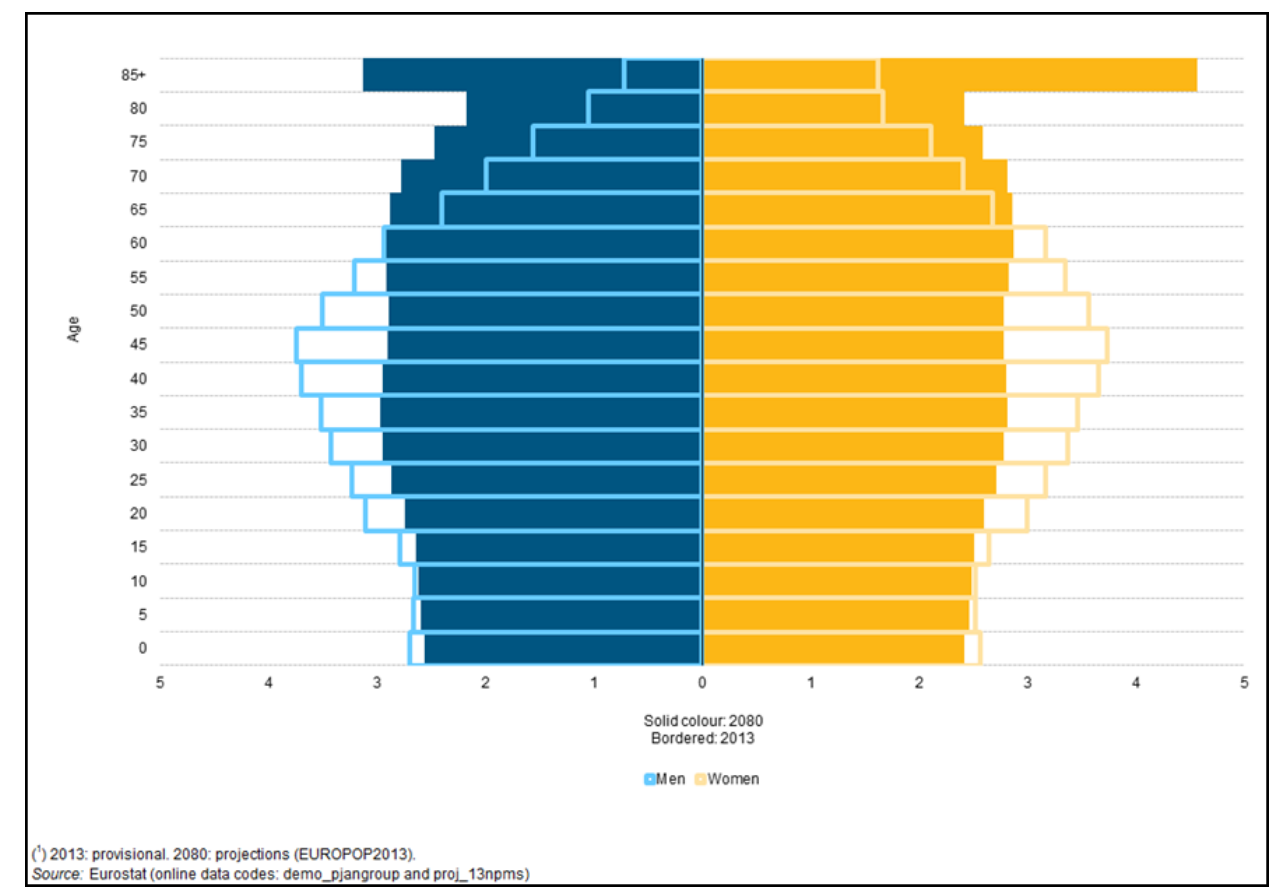

Figure 1. EU Population Pyramid (2013 and 2080 estimate).

With such an ageing population in Europe, demand for health insurance could grow along with that of private pensions, whereby governments will encourage the savings into insurance plans for 
future pensions. Increasing numbers of people at old and very old ages will pose major challenges for health-care systems. However, people are also living longer with less disability and fewer functional limitations (Christensen et al. 2009).

An ageing population also results in less people in the working age groups and more in retirement. Implications for the insurance industry will be encountered due to increasing costs from pensions, health care and aged care, assuming current economic and social security structures continue unchanged. Due to these increasing costs of state provided age pensions, many Organisation for Economic Cooperation and Development (OECD) governments moved to equalise male and female eligibility ages for commencement of age pensions. In many EU countries, public pensions have become the largest single budget item (Pignal 2012). The standard retirement age of 65 is planning to be raised by many governments across Europe, whereby Denmark, the Netherlands and Germany plan to reach the retirement age of 67, as it is currently in Iceland and Norway. The UK wants to increase it further to 68 years (Beernaert and Hoekstra 2014). Thus, increasing the retirement age is an approach used by some governments to ameliorate the impact on public finances of an ageing population. The practice of gradual or phased retirement is becoming more popular however this could impact social security rules and pension scheme rules. ${ }^{3}$

\subsection{Education}

People are now better educated, resulting in more questions being asked when purchasing insurance products. European higher education is said to be diverse and this is regarded as one of its major strengths. However, "a common path towards transparency, quality, growth, efficiency and excellence is regarded a prerequisite for making Europe one of the strongest education and economic leaders in the world" (EMSU 2009).

Between 2006 and 2011, there was a 1.6\% increase in the proportion of pupils and students in tertiary education, reaching an overall of $21.7 \%$ in the EU. Between 2007 and 2012, the overall share in the EU of early leavers from education and training decreased by $2.2 \%$, reaching $12.7 \%$ in 2012 . According to the strategic framework for European cooperation in education and training, this number is benchmarked to be reduced even further by 2020 to less than $10 \%$ - a level already reached by thirteen EU Member States in 2012 (Eurostat 2014).

Hence consumers have become more risk aware, tending to be insurance inclined in order to protect their ever increasing number and cost of goods and assets. Insurance companies must therefore take better care of their clients in order to retain them. With insurance, people look at service whenever a claim arises and how fast and efficient one solves a claim. There has been a growing interest in financial literacy and financial education over the past years. As a result, the financial market place has become more dynamic and complex affecting individuals' financial decisions such as which retirement plan workers should select (Bosshardt and Walstad 2014).

Financial development is widely recognised as an important determinant of economic growth, with a large literature examining the determinant of the supply of financial intermediation services (Levine 2005). In low-income countries, surveys and studies show that financial literacy, and knowledge of and attitudes towards insurance products play an important role in take-up ( $\mathrm{Xu}$ and Zia 2012). For example, Cohen and Young (2007) note that the main reason for non-renewal of insurance policies issued by a company in Guatemala was lack of understanding.

\subsection{Community Values, Attitudes and Cultures}

Anti-discrimination legislation has been brought about by many reasons including community disapproval of discrimination based on gender, marital status, religion, disability and race. It also results in ongoing public debates, questioning the right of life insurers and pension schemes to

3 Refer to Redaymulvey(2000) for further reading on gradual retirement in Europe. 
be exempted from such legislation, as well as to what extent insurers have in limiting the ability to discriminate in their underwriting (Avraham et al. 2013). In fact, as from 21st December 2012, insurance companies in the EU had to charge the same prices to men and women for the same insurance products, enabling gender-neutral pricing across EU countries. The change had an effect on all new contracts for products of the labour insurance market. Pricing had to be based on other risk factors rather than gender (European Commission 2012).

Values and norms have been changing over the past years and can be seen in calls for recognition of de facto partners and same-sex partners, along with married opposite-sex partners. This will affect benefits payable to spouses from pension schemes. The insurance industry is also faced with constraints on the types of questions insurers ask in their proposal forms such as sexual orientation. Attitudes of people also have an impact on the insurance market when making claims along with the extent to which people believe that under-insuring is a prudent method of decreasing their expenses. In an insurance industry, the level of criminal activity in a community could impact the level of claims. This could be higher in urbanised areas since there is a greater concentration of assets leading to increased opportunities for crime and for evading detection (Esho et al. 2004). Urban concentration increases the rate of interaction amongst individuals; hence more activities are undertaken in close proximity to neighbours and in turn some insurers use urbanization as a proxy for loss probability (Browne et al. 2000). Furthermore, this criminal effect on insurance is explored by (Litton 1982) whereby insurers can influence the behaviour of potential victims in such a way as to prevent the crimes from which they may have otherwise suffered.

There has also been a shift in Western culture, away from the traditional systems of pooling and sharing but towards a focus on the rights and interests of individuals. This has brought about a rapid move towards an individual account format for savings through life insurance and pension schemes (Shepherd 2010), which is also related to people changing jobs more often than seen before. National culture has a strong impact on insurance purchase decisions. Consumers may base their decisions on cultural beliefs not only economic rationality (Lemaire and Park 2012). Studies show that until the 19th century, several European nations condemned and banned life insurance on religious grounds (Zelizer 1979). Moreover, the religious inclination of a population may affect its risk aversion (Beck and Webb 2003). This will lead to more sharia-compliant insurance products being offered such as Takaful insurance.

\section{Technological and Physical Environment}

\subsection{Advances in Technology}

Technology has a two-fold effect on the insurance industry; on the one hand technology has been used by insurers since the 1960s and has enabled them to improve their services. However, many insurers have struggled to cope with the ever-changing technological environment. Furthermore, business mentality has now changed and placing the customer at the centre of the organisation is essential for the business to prosper. Insurers must understand customer's lifestyles to create products that satisfy these needs and technology can be a powerful tool in doing this (KMPG 2014).

Product design and improvement has allowed insurance companies to branch out into new areas of insurance. For example, photovoltaic panels are now becoming increasingly popular; in fact $5 \%$ of electricity demand in Europe is supplied by solar means (SolarPower Europe 2016). This has created an opportunity for insurance companies to provide cover for the risk associated with such panels. Moreover, some industries have evolved significantly such that they will require a different form of insurance. For example, the betting industry has grown significantly in size and complexity such that the demand for insurance cover has changed from property insurance to possibly cover what is more akin to financial derivatives (Cortis 2015).

Mobile devices have evolved tremendously such that they can be considered as the new personal computers whereby individuals have come to rely on mobile devices for purchasing goods and services 
(Rauch 2011). The increase in portability of our technological devices has made them much more prone to theft making the need to insure these devices a necessity.

Another advantage of technology is that more accurate information is now being obtained through telematics based insurance. This is a small technological device that is attached to an insured vehicle that transmits valuable information to the insurer via a wireless network. As a result, policyholders pay their motor insurance premium on the basis of the risk they pose as opposed to the traditional way of calculating premiums, whereby a policyholder will pay a premium which reflects factors such as age and car value (Azzopardi and Cortis 2013).

The growth of internet connected devices and sensors affecting the availability of real time information gives insurers an opportunity to have an edge over competition. This information can be used to offer more affordable prices, better underwriting and loss control. Also, advances in artificial intelligence techniques allow insurers to base decisions on technology, as opposed to just using technology as a means of processing data (PwC 2012). Blockchain technology, a distributed ledger that has been gaining a lot of attention, can provide insurers with opportunities for new products, improved fraud detection and lowering of administrative costs (Lorenz et al. 2016).

Another advantage of technology is that insurance companies may be able to reduce new business acquisition costs. Traditionally intermediaries would take note of customer and business requirements and then seek to find insurance products that match those needs. Nowadays, it is possible to get a quotation, renew a policy, pay your excess, fill in a claims form and also compare policies online. Therefore, the insured is cutting out the middleman and dealing directly with insurance companies. The target audience for this kind of direct selling would be customers looking for simplicity and convenience. This can be an advantage to insurers as they will no longer have to pay commission to intermediaries, thereby allowing them to retain all the profits from a sale (PwC 2012).

In recent years, mobile devices have come a long way and now aren't simply used as portable telephones. Smartphones and tablets have taken over the consumer world and this has also affected the way in which business is conducted (Deloitte Consulting LLP 2013). Therefore, mobile technology is a significant trend in information technology as users may conduct business transactions at their own convenience by using their mobile phones (Lee et al. 2007). Mobile technology can be used as a distribution channel and also as a means of offering customers a means of communication at all times. It can help attract new customers and also retain existing ones by increasing customer satisfaction (Ernst \& Young 2014). Insurers who decide to invest in mobile technology may use it as a tool in order to give them a cutting edge over competitors. Insurers must also be aware of the responsibility that comes with holding sensitive information about clients for example credit card data. Hacking can lead to substantial liabilities and losses including costs of identifying the cause and putting corrective action into place. This problem is growing and becoming even more of a worry for insurers as anti-hacking techniques such as firewall and antivirus software are not that reliable as hackers continuously find innovative ways of evading them. Therefore, insurers need to step up and invest more resources into proactively responding and identifying any incoming threats. Although the threat can never be fully extinguished, insurers must aim to reduce it to the lowest possible level (Deloitte Consulting LLP 2013).

Advances in medicine and health care is one of the reasons for the increase in life expectancy at birth, which can be seen over the past century. Other factors for such an increase include reductions in infant mortality, improved standards of living, improved lifestyles and better education (Eurostat 2014). Advances in medical technology can be a worry for health insurers in view of the impact on mortality rates and morbidity. Today more tests and surgical procedures are being carried out. Moreover, today there is a much wider universe of drugs which reduces the risk of sickness, disability and death from particular causes. These developments have led to an increase in the number of claims and also the cost of claims, as new technology can be very costly (Shepherd 2010).

The long-term side effects of new technologies in any area from traditional equipment to cosmetic enhancements are unknown, leading to potential latent claims. Consider a scenario in which mobile 
phones are found to be carcinogenic - the experience on claims may be as substantial as the insurance exposure to asbestos.

\subsection{The Physical Environment}

\subsubsection{Climate change}

Climate change is fast becoming a risk to all society as the increase in emissions of greenhouse gases has taken its toll on our climate. Furthermore, as one of the largest and most powerful industries in the world, the insurance industry must be pro-active and respond to such a threat (World Economic Forum 2016). As with most problems basic knowledge and understanding about the situation is required in order to be able to generate suitable solutions and action plans. Therefore, insurers may start off with research in order to create risk models which take climate change into consideration. The solutions reached should help both the industry as well as society as a whole (Mills 2009).

So far insurers such as Munich RE (Munich, Germany), Tokio Marine Holdings (Chiyoda, Tokyo, Japan), RMS (Newark, CA, USA) and CGU (Melbourne, Australia) have worked directly with the Intergovernmental Panel on Climate Change whilst others have worked with catastrophe modelling firms in order to better incorporate climate change in their analysis (Mills 2005).

Governments have also teamed up with insurers to introduce innovative ways of spreading financial risk. The carrying out of research, land-use planning, educating citizens, emission reductions, planning ahead for disasters and provision of backstop reinsurance would fall under the roles of government (UNEP 2015). For example, in May 2015 the new G7 Initiative on Climate Risk Insurance was presented. The aim of the initiative is to encourage developing countries to combat climate induced and other natural disasters. The initiative is also a significant development in improving the collaboration between national and international political institutions, and also the insurance industry (Herweijer et al. 2009).

It may also be an opportunity for insurance companies to improve their reputation by operating in an environmentally friendly manner; thus being conscious about energy consumption and promoting energy saving techniques. This can help retain customers but can also help attract new customers who take such factors into consideration when choosing an insurance company.

Another opportunity is that of insurers and reinsurers offering advisory services, this allows them to use their expertise in climate risk management and risk transfer in order to assist third parties in adapting to climate change (Anderson and Bausch 2006).

\subsubsection{Natural Disasters}

One may also note a link between climate change and natural disasters: as our climate continues to change, natural disasters are expected to increase. For example, precipitation patterns could change leading to more floods or more droughts (Guha-Sapir et al. 2013).

Natural disasters are inclusive of a wide range of catastrophes, and at times the impact of such disasters can be extremely severe. Natural disasters may be categorised into five main subgroups: geophysical (e.g., earthquakes), meteorological disasters (e.g., storms), hydrological disasters (e.g., floods), climatological disasters (e.g., droughts) and biological disasters (e.g., insect infestations) (Strum and Oh 2009). Statistics show that over the last century the number of natural disasters have increased. Although the worldwide share of natural disasters cost is low in Europe, (Strum and Oh 2009), some European undertakings may be insuring risks based elsewhere.

One catastrophic event can have disastrous effects and leave insurance and reinsurance companies obliged to pay out large amounts of money as compensation to policyholders. Therefore, in order for insurance and reinsurance companies to protect their business and not place themselves in potentially devastating situations, they have resorted to increasing the premiums charged to customers and also minimizing their exposure to risks (Jones 2011). 
However, insurance companies are faced with the problem of "spreading of risk" when dealing with natural disasters. This problem arises as people who live in areas where there is, for example a high risk of an earthquake occurring will be more inclined to purchase insurance to protect them from such an event. On the other hand, if there is hardly any risk of an earthquake occurring, then people may not feel the need to purchase such insurance. In this respect the premiums collected may not be enough to cover the cost of claims.

Different individuals will have alternative perceptions of the same risk (Spinnewijn 2013). Different perceptions may stem from the fact that some individuals may not be aware of the risk they are exposed to whilst others, although aware of the risk, still do not feel the need to purchase insurance and would rather bear $100 \%$ of the risk themselves. These different views may have an effect on the contract design and hence it is an important consideration for insurance companies (Spinnewijn 2013).

New ideas and methods of transferring risk are now being used. One such method involves using Alternative Risk Transfers (ARTs) whereby risks are spread through global securities markets. This is common amongst reinsurers who do not want to shoulder the risk of events which do not happen often, but when they do, have catastrophic consequences. An example of ARTs is catastrophe bonds, which in recent years have proven to be very common (Jones 2011).

Biological invasion occurs when non-native organisms spread to areas outside their usual range. In recent years the number of invasions of exotic species has increased, amplifying the problem, as these invasions can lead to economic losses (Jankovic and Petrovskii 2013). This leads to the problem of uncertainty of future incomes which complicates matters with regards to both short-term production decisions as well as long-term planning (Miranda and Vedenov 2001). Again, the insurance and reinsurance industry can develop innovative ways of risk sharing for example through index-based insurance contracts. When used in developing countries, governments are given the opportunity to develop agricultural insurance within the respective country and then at a reduced transaction cost they may transfer the non-diversifiable component of risk to the global markets (Miranda and Vedenov 2001).

\section{Conclusions}

The insurance industry is vital to the European market in both well developed and developing regions as it also has a ripple effect on other industries both within the financial and non-financial realm. This makes a generic overview of the industry an important update to be made. We used a PEST analysis to update the main political, legislative, economic, social, demographic, technological and environmental changes that affect the industry as a whole. The main discussions outlined during the report and the findings are summarised in Table 1.

This table lists the main drivers which have been identified as key in the PEST process, including some examples. It is important to note that this list is not exhaustive and thus there may be other direct and/or indirect factors which could play an important role in this regard. Moreover, this paper is not an attempt to determine the most significant risk. Indeed, the aim has been to bring forward a discussion and not prophesize the next cataclysmic change. More studies like (World Economic Forum 2016) examining the perceived major risks by professionals, regulators and academics would be recommended.

Notwithstanding, the industry itself and associated entities, such as actuarial societies, have been acknowledging these changes and have been proactive in dealing with the new risks ranging from longevity to cyber risks to climate change. 
Table 1. Summary of main drivers.

\begin{tabular}{|c|c|c|}
\hline & Main Drivers & Example \\
\hline $\begin{array}{l}\text { Political and Legislative } \\
\text { Factors }\end{array}$ & $\begin{array}{l}\text { Stricter legislation } \\
\text { Harmonisation } \\
\text { Specific laws in a class of business } \\
\text { Indirect } \\
\text { Judicial decisions } \\
\text { Political environment } \\
\text { Tax incentives }\end{array}$ & $\begin{array}{l}\text { Political forces } \\
\text { Solvency II } \\
\text { Less public healthcare } \\
\text { More traffic enforcement } \\
\text { Different interpretation of policies } \\
\text { Protectionism } \\
\text { Additional investment opportunities }\end{array}$ \\
\hline $\begin{array}{l}\text { Economical and Business } \\
\text { Environment }\end{array}$ & $\begin{array}{l}\text { Financial crises } \\
\text { Interest rates } \\
\text { Inflation } \\
\text { Foreign exchange rates } \\
\text { Demography and economic growth } \\
\text { Underwriting cycle }\end{array}$ & $\begin{array}{l}2007-2009 \\
\text { Current low interest rate scenario putting } \\
\text { pressures on defined benefit schemes } \\
\text { Increased medical costs } \\
\text { Home vs foreign currency } \\
\text { Reduction in mortality rates } \\
\text { Soft vs. hard markets }\end{array}$ \\
\hline $\begin{array}{l}\text { Social and Cultural } \\
\text { Environment }\end{array}$ & $\begin{array}{l}\text { Work and employment patterns } \\
\text { Fertility, mortality, migration } \\
\text { Ageing population } \\
\text { Education } \\
\text { Common values, attitudes }\end{array}$ & $\begin{array}{l}\text { Gig economy changing pension demands } \\
\text { Higher generation gap between parents and } \\
\text { children } \\
\text { Term care insurance } \\
\text { Greater demand for insurance products but } \\
\text { better service required } \\
\text { Antidiscrimination laws leading to same pricing } \\
\text { between genders }\end{array}$ \\
\hline $\begin{array}{l}\text { Technological and } \\
\text { Physical Environment }\end{array}$ & $\begin{array}{l}\text { Direct technological effects } \\
\text { New technology to cover } \\
\text { Disruptive technologies } \\
\text { Climate change } \\
\text { Natural disasters }\end{array}$ & $\begin{array}{l}\text { Blockchain, telematics } \\
\text { Photovoltaic panels } \\
\text { New products by competing industries } \\
\text { Risk modelling improvements } \\
\text { Pest damage to crops }\end{array}$ \\
\hline
\end{tabular}

Acknowledgments: We thank Nick Foster for his invaluable comments and criticisms of this paper. We also thank insurance practitioners who discussed this PEST analysis at the start of the project as well undergraduates following a major in insurance studies (2011-2014) within their bachelor's in commerce at The University of Malta.

Author Contributions: Charmaine Barbara, Roberta Perotti, Claudia Sammut and Antoine Vella have written initial drafts on the economical/business, technological/physical, social/cultural and political/legislative factors respectively. Dominic Cortis has conceived the project, written the article and made the necessary changes to update the different iterations of this article.

Conflicts of Interest: The authors declare no conflict of interest.

\section{References}

Alhgrim, Kevin C., and Stephen P. D'Arcy. 2012. The Effect of Deflation or High Inflation on the Insurance Industry. Available online: https:/ /www.casact.org/research/NAACCRG/final_report.pdf (accessed on 19 April 2015).

Anderson, Jason, and Camilla Bausch. 2006. Climate Change and Natural Disasters: Scientific Evidence of a Possible Relation between Recent Disasters and Climate Change. Brussels: European Parliament's Environment, Public Health and Food.

Andrietti, Vicenzo. 2000. Occupational Pensions and Interfirm Job Mobility in the European Union. Evidence from the ECHP survey. ISER Working Paper Series 2000-07; Rome: Department of Economics, University of Tor Vergata.

Atkinson, Margaret E., and David C. M. Dickson. 2011. An Introduction to Actuarial Studies, 2nd ed. Surrey: Edward Elgar.

Avraham, Ronen, Kyle D. Logue, and Daniel B. Schwarcz. 2013. Understanding Insurance Anti-Discrimination. Ann Arbor: University of Michigan Law School Scholarship Repository Law \& Economics Working Papers.

Azzopardi, Marika, and Dominic Cortis. 2013. Implementing Automotive Telematics for Insurance Covers of Fleets. Journal of Technology Management and Innovation 8: 59-67. [CrossRef]

Baluch, Faisal, Stanley Mutenga, and Chris Parsons. 2011. Insurance, Systemic Risk and the Financial Crisis. The Geneva Papers on Risk and Insurance-Issues and Practice 36: 123-63. [CrossRef] 
Beck, Thorsten, and Ian Webb. 2003. Economic, Demographic, and Institutional Determinatns of Life Insurance Consumption across Countries. The World Bank Economic Review 17: 51-88. [CrossRef]

Beernaert, Joris, and Corine Hoekstra. 2014. Raising the real retirement age. The Actuary, May 8.

Blanchard, Olivier. 2006. European Unemployment: the evolution of facts and ideas. Economic Policy 21: 5-59. [CrossRef]

Borghans, Lex, and Bart H. H. Golsteyn. 2010. Job Mobility in Europe, Japan and the United States. British Journal of Industrial Relations 50: 436-56. [CrossRef]

Börsch-Supan, Axel. 2010. Work Disability: The Effects of Demography, Health, and Disability Insurance. In Research Findings in the Economics of Aging. Edited by David A. Wise. Chicago: The University of Chicago Press, pp. 37-58.

Bosshardt, William, and William B. Walstad. 2014. National Standards for Financial Literacy: Rationale and Content. The Journal of Economic Education 45: 63-70. [CrossRef]

Browne, Mark J., JaeWook Chung, and Edward W. Frees. 2000. International Property-Liability Insurance Consumption. The Journal of Risk and Insurance 67: 73-90. [CrossRef]

Business Case Studies. 2013. How Lloyd's Responds to Changes in the Business Environment. Available online: http:/ / businesscasestudies.co.uk/lloyds-of-london/how-lloyds-responds-to-changesin-the-business-environment/key-challenges-facing-the-lloyds-market.html\#axzz2j1rmxheZ (accessed on 20 September 2014).

CEA. 2006. The Contribution of the Insurance Sector to Economic Growth and Employment in the EU. Available online: http:/ /docshare01.docshare.tips/files/18470/184702260.pdf (accessed on 10 November 2016).

Christensen, Kaare, Gabriele Doblhammer, Roland Rau, and James W. Vaupel. 2009. Ageing Populations: The Challenges Ahead. The Lancet 374: 1196-208. [CrossRef]

Cohen, Monique, and Pamela Young. 2007. Using Microinsurance and Financial Education to Protect and Accumulate Assets. In Reducing Global Poverty: The Case for Asset Accumulation. Edited by Caroline Moser. Washington: Brookings Institute Press, pp. 208-24.

Cortis, Dominic. 2015. Expected Values and Variances in Bookmaker Payouts: A Theoretical Approach towards setting Limits on Odds. The Journal of Prediction Markets 9: 1-14.

Crespi, John M. 2005. The Financing of Regulatory Agencies. Journal of Regulatory Economics 27: 95-113.

Crompton, Rosemary, and Clare Lyonette. 2006. Work-Life 'Balance' in Europe. Acta Sociologica 49: 379-93. [CrossRef]

Deloitte Consulting LLP. 2013. Insurance Tech Trends 2013: Elements of Postdigital. Available online: https://www2.deloitte.com/content/dam/Deloitte/us/Documents/financial-services/us-fsiinsurance-tech-trends-2013.pdf (accessed on 20 September 2014).

Doff, René. 2008. A Critical Analysis of the Solvency II Proposals. The Geneva Papers 33: 193-206. [CrossRef]

Dwight, Lee R. 1996. Why is Flexible Employment Increasing? Journal of Labor Research 17: 543-53.

European Insurance and Occupational Pensions Authority (EIOPA). 2014. Financial Stability Report EIOPA-FS-14/105. pp. 13-24. Available online: https:/ / eiopa.europa.eu/Publications/Reports/EIOPA-FS14-105\%20Financial\%20Stability\%20Report-\%20Autumn\%202014.pdf (accessed on 5 March 2016).

Ernst \& Young. 2010. Solvency II Internal Models. Available online: http:/ /www.ey.com/Publication/vwLUAssets / Solvency_internal_models/\$FILE/Solvency\%20internal\%20models.pdf (accessed on 20 December 2015).

Ernst \& Young. 2014. Mobile Technology in Insurance. Available online: http://www.ey.com/Publication/ vwLUAssets/EY-mobile-technology-in-insurance/\$FILE/EY-mobile-technology-in-insurance.pdf (accessed on 20 August 2014).

Esho, Neil, Anatoly Kirievsky, Daniel Ward, and Ralf Zurbruegg. 2004. Law and the Determinants of Property-Casualty Insurance. The Journal of Risk and Insurance 71: 265-83. [CrossRef]

European Centre for Strategic Management of Universities (EMSU). 2009. Higher Education Governance Reforms Across Europe. Brussels. Available online: http:/ / doc.utwente.nl/88691/1/c9hdb101\%20modern\% 20project\%20report.pdf (accessed on 2 March 2015).

European Commission. 2012. Factsheet: EU Rules on Gender-Neutral Pricing in Insurance. Available online: http:/ / ec.europa.eu/justice/gender-equality/files/unisex_insurance_en.pdf (accessed on 2 March 2015).

Eurostat. 2014. Mortality and Life Expectancy Statistics. Available online: http://epp.eurostat.ec.europa.eu/ statistics_explained/index.php/Mortality_and_life_expectancy_statistics (accessed on 2 March 2015).

Eurostat. 2017. Household Composition Statistics. Available online: http://ec.europa.eu/eurostat/statisticsexplained/index.php/Household_composition_statistics (accessed on 1 March 2017). 
Frejka, Tomas. 2008. Determinants of Family Formation and Childbearing during the Societal Transition in Central and Eastern Europe. Demographic Research 19: 139-70.

Garrett, Stephen. 2013. Introduction to the Mathematics of Finance. London: Elsevier.

Gorvett, Richard W. 2001. Foreign Exchange Rate Risk: Institutional Issues and Stochastic Modeling. In Financial and Accounting Systems and Issues Associated with the Globalization of Insurance. Arlington: Casualty Actuarial Society, pp. 19-52.

Grossman, Joy M., and Paul B. Ginsburg. 2004. As The Health Insurance Underwriting Cycle Turns: What Next? Health Affairs 23: 91-102. [CrossRef] [PubMed]

Guha-Sapir, Debarati, Philippe Hoyois, and Regina Below. 2013. Annual Disaster Statistical Review 2012. Brussels: CRED.

Harrington, Scott E. 2009. The Financial Crisis, Systemic Risk, and the Future of Insurance Regulation. The Journal of Risk and Insurance 76: 785-819. [CrossRef]

Herweijer, Nicola, Nicola Ranger, and Robert E.T. Ward. 2009. Adaptation to Climate Change: Threats and Opportunities for the Insurance Industry. The Geneva Papers 34: 360-80. [CrossRef]

International Monetary Fund (IMF). 2009. Global Financial Stability Report. Available online: https://www.imf. org/external/pubs/ft/gfsr/2009/01/pdf/text.pdf (accessed on 19 April 2015).

Insurance Europe. 2014. European Insurance in Figures (Statistics no 50). Available online: https://www. insuranceeurope.eu/statistics-n\%C2\%B050-european-insurance-figures (accessed on 2 March 2015).

Jankovic, Masha, and Sergei Petrovskii. 2013. Gypsy month invasion in North America: A simulation study of the spatial pattern and the rate of spread. Ecological Complexity 14: 132-44. [CrossRef]

Jenkins, Patrick. 2016. Banking can learn from insurance on systemic risk. The Financial Times, January 25.

Jones, Richard B. 2011. 20\% Chance of Rain: Exploring the Concept of Risk. Hoboken: Wiley-Blackwell.

Karl, Kurt, Thomas Holzheu, and David Laster. 2010. The Impact of Inflation on Insurers. (Sigma Series 4/2010). Available online: http://www.bvzl.de/Newsletter/2011_03/Spotlight_01_EN.pdf (accessed on 19 April 2015).

KMPG. 2014. How Well Is the Life Insurance Industry Keeping Pace with Rapidly Changing Technology? London: KPMG International Cooperative.

Lee, Ching-Chang, Hsing Kenneth Cheng, and Hui-Hsin Cheng. 2007. An empirical study of mobile commerce in insurance industry: Task-Technology fit and individual differences. Decision Support Systems 43: 95-110. [CrossRef]

Lemaire, Jean, and Sojung C. Park. 2012. The Impact of Culture on the Demand for Non-Life Insurance. Insurance and Risk Management 42: 501-27.

Levine, Ross. 2005. Finance and Growth: Theory and Evidence. In Handbook of Economic Growth. Edited by Philippe Aghion and Steven N. Durlauf. Amsterdam: Elsevier, Chapter 12, Volume 1, Part A, pp. 865-934.

Liedtke, Patrick M., and Kai-Uwe Schanz. 2010. The Global Financial Crisis and the Insurance Industry: Frequent Asked Questions. The Geneva Association. Available online: https://www.genevaassociation.org/media/ 78737/ga2009-ifsc9.pdf (accessed on 19 April 2015).

Linder, Ulf, and Vesa Ronkainen. 2004. Solvency II-Towards a New Insurance Supervisory System in the EU. Scandinavian Actuarial Journal 2004: 462-74. [CrossRef]

Litton, Roger A. 1982. Crime Prevention and Insurance. The Howard Journal of Criminal Justice 21: 6-22. [CrossRef]

Lorenz, Johannes-Tobias, Björn Münstermann, Matt Higginson, Peter B. Olesen, Nina Bohlken, and Valentino Ricciardi. 2016. Blockchain in Insurance-Opportunity or Threat? McKinsey \& Company. Available online: http:/ / www.mckinsey.com/industries/financial-services/our-insights/blockchain-ininsurance-opportunity-or-threat (accessed on 14 November 2016).

Mills, Evan. 2005. Insurance in a Climate of Change. Science 309: 1040-44. [CrossRef] [PubMed]

Mills, Evan. 2009. A Global Review of Insurance Industry Responses to Climate Change. The Geneva Papers on Risk and Insurance-Issues and Practice 34: 323-59. [CrossRef]

Miranda, Mario, and Dimitry V. Vedenov. 2001. Innovations in Agricultural and Natural Disaster Insurance. American Journal of Agricultural Economics 83: 650-55. [CrossRef]

OECD. 2011. Key Policy Conclusions from the Crisis. In The Impact of the Financial Crisis on the Insurance Sector and Policy Responses. Paris: OECD, pp. 55-7.

OECD-UNDESA. 2013. World Migration in Figures. Available online: http:/ /www.oecd.org/els/mig/WorldMigration-in-Figures.pdf (accessed on 2 March 2015). 
Parker, George, and Alex Barker. 2015. UK call for "multicurrency" EU triggers ECB alarm. The Financial Times, December 4.

Pignal, Stanley. 2012. Europe's retirement ages in the spotlight. Financial Times, February 16.

PricewaterhouseCoopers (PwC). 2012. Insurance 2020: Turning Change into Opportunity. Available online: https: //www.pwc.com/gx/en/insurance/pdf/insurance-2020-turning-change-into-opportunity.pdf (accessed on 14 November 2016).

Rauch, Marta. 2011. Mobile Documentation: Usability Guidelines, and Considerations for Providing Documentation on Kindle, Tablets, and Smartphones. Paper presented at IEEE Professional Communication Conference (IPCC), Cincinnati, OH, USA, 17-19 October.

Redaymulvey, Genevieve. 2000. Gradual Retirement in Europe. Journal of Aging and Social Policy 11: 49-60. [CrossRef] [PubMed]

Roberts, Elizabeth. 2015. Families facing a "lottery" over when they need to pay their nanny a pension. The Telegraph, May 17.

Sander, Victoria, and Wolfgang Krauel. 2013. Life Changing: The Outlook for Life Insurance in Europe. Available online: http://www.linklaters.com/pdfs/mkt/london/14609_Linklaters_TL_PM_eVersion.pdf (accessed on 2 March 2015).

Scarr, Sandra, Deborah Phillips, and Kathleen McCartney. 1989. Working Mothers and their Families. American Psychologist 44: 1402-9. [CrossRef]

Schiro, James J. 2006. External Forces Impacting the Insurance Industry: Threats from Regulation. The Geneva Papers 31: 25-30. [CrossRef]

Shepherd, John. 2010. The Context of Actuarial Work. In Understanding Actuarial Management: The Actuarial Control Cycle. Edited by Clare Bellis, Richard Lyon, Stuart Klugman and John Shepherd. Sydney: The Institute of Actuaries of Australia, pp. 105-32.

SolarPower Europe. 2016. Solar Market Report \& Membership Directory. Available online: http:/ / www.solarpowereurope.org/fileadmin/user_upload/documents/2015_Market_Report/SPE16_ Members_Directory_high_res.pdf (accesssed on 27 May 2017).

Spinnewijn, Johannes. 2013. Insurance and Perceptions: How to Screen Optimists and Pessimists. The Economic Journal 123: 606-33. [CrossRef]

Strum, Tristan, and Eric Oh. 2009. Natural disasters as the end of the insurance industry? Scalar competitive strategies, Alternative Risk Transfers, and the economic crisis. Geoforum 41: 154-63. [CrossRef]

Summer, Judith. 2010. Insurance Law and the Financial Ombudsman Service. London: Taylor \& Francis.

Tsang, Flavia, Michael Rendall, Charlene Rohr, and Stijn Hoorens. 2011. Emerging Trends in Earning Structures of Couples in Europe: Short Statistical Report No. 5. Cambridge: RAND Europe.

Twisk, Divera A.M., and Colin Stacey. 2007. Trends in Young Driver Risk and Countermeasures in European Countries. Journal of Safety Research 38: 245-57. [CrossRef] [PubMed]

Tye, Sue, and Anne Latrémolière. 2007. UK pensions simplification: Implications for overseas employees. Pensions: An International Journal 12: 164-70. [CrossRef]

United Nations Environment Programme (UNEP). 2015. G7 Countries, Top Insurers Team Up for Climate Change Resilience. Available online: http://www.unep.org/newscentre/g7-countries-top-insurers-team-climatechange-resilience (accessed on 20 August 2015).

Vaughan, Therese M. 2009. The Implications of Solvency II for U.S. Insurance Regulation. Networks Financial Institute Policy Brief No. 2009-PB-03; Terre Haute: Indiana State University.

World Economic Forum. 2016. The Global Risks Report 2016, 11th Edition. Geneva: World Economic Forum.

Xu, Lisa, and Bilal Zia. 2012. Financial Literacy Around the World: An Overview of the Evidence with Practical Suggestions for the Way Forward. World Bank Policy Research Working Paper; Washington, DC, USA: World Bank.

Zelizer, Viviana. 1979. Morals and Markets: The Development of Life Insurance in the United States. The Journal of Economic History 40: 441-42.

(C) 2017 by the authors. Licensee MDPI, Basel, Switzerland. This article is an open access article distributed under the terms and conditions of the Creative Commons Attribution (CC BY) license (http:/ / creativecommons.org/licenses/by/4.0/). 